\title{
ВІК ДИТИНСТВА ТА ЙОГО ПЕРІОДИЗАЦІЯ У БАЧЕННІ «ВЧЕНОЇ КУЛЬТУРИ» ГЕТЬМАНЩИНИ ХVIII ст.
}

\author{
I. О. Сердюк
}

Сердюк I. O. Вік дитинства та його періодизація у баченні «вченої культури» Гетьманщини XVIII ст. У статті подана спроба 3'ясувати вікові рамки дитинства та його періодизацію у баченні вченої культури Гетьманщини. Йдеться передусім про релігійні настанови, моралізаторства і філософські тексти, котрі могли впливати на своїх реципієнтів та сприяти перенесенню бачення дитини на рівень популярної культури. Встановлено, що найважливішим віковим рубежем у цьому сенсі був семирічний вік, з якого людина набувала «церковної дієздатності» і ставала відповідальною за свої вчинки перед Богом. Важливим віковим вододілом був також мінімальний шлюбний вік (14 і 12) років, з якого дитина вважалася достатньо дорослою для створення родини.

Ключові слова: вік; вчена культура; Гетьманщина; дитина; дитинство; періодизація; популярна культура.

Сердюк И. А. Возраст детства и его периодизация в видении «ученой культуры» Гетманщины XVIII века. В статье представлена попытка изучить возрастные рамки детства и его периодизацию в видении ученой культуры Гетманщины. Речь идет, прежде всего, о религиозных установках, морализаторствах и философских текстах, которые могли влиять на своих реципиентов и способствовать переносу видения ребенка «образованным миром» на уровень популярной культуры. Важнейшим возрастным рубежом в этом смысле был семилетний возраст, с которого человек приобретал «церковную дееспособность» и становился ответственным перед Богом за свои поступки. Важным возрастным водоразделом был также минимальный брачный возраст (14 и 12) лет, с которого ребенок считался достаточно взрослым для создания семьи.

Ключевые слова: возраст; ученая культура; Гетманщина; ребенок; детство; периодизация; популярная культура.

Serdyuk I. O. The Age of Childhood and its Periodization in the View of the "Academic Culture" of the Hetmanschyna of the $18^{\text {th }}$ Century. The article attempts to find out the age limits of childhood and its periodization in the vision of the learned culture of the Hetmanate. First of all, I tell about religious instruction and philosophical texts that could influence their recipients and contribute to bringing the child's vision to a popular culture. It was established that the most important age-line in this sense was the age of seven, from which man acquired "church capacity" and became responsible for his actions before God. An important age dividend was also the minimum marriage age (14 and 12) years, from which the child was considered sufficiently grown to create a family.

Keywords: age; scientific culture; Hetmanschyna; child; childhood; periodization; popular culture.

Попри великий досвід світової історіографії, історія дитинства на матеріалах українського домодерного суспільства вивчена надзвичайно слабко ${ }^{1}$. Це узагальнення хронологічно й територіально можна звузити і на Гетьманщину, функціонування котрої набагато краще вивчене 3 точки зору політики, економіки, скасування автономії, аніж через призму життя «маленької людини». Необхідно визнати, що сьогодні українська історіографія має ряд розвідок стосовно дитинства в Гетьманщині ${ }^{2}$, однак лише одна 3 них безпосередньо стосується одвічної та першопочаткової проблеми дефініцій та визначення вікових рамок дитинства ${ }^{3}$. Хоча, здавалося, мусило б бути навпаки, адже історики спочатку мають сфокусувати оптику дослідницького інструментарію та максимально визначитися з тим, хто буде фігурувати на сторінках їхніх досліджень як дитина. 3 іншого боку, виокремлення різних маркерів приналежності до дитячого світу та їх застосування в різних ситуаціях, окремими соціальними мікрогрупами та суспільними інституціями вже має самостійний пізнавальний інтерес. Такі ж маркери застосовувалися й до періодизацій дитячого віку, який ніколи не сприймався як щось неподільне та однорідне.

Свого часу відома дослідниця історії дитинства Суламіф Шахар (Shulamith Shahar) грунтовно проаналізувала середньовічні медичні праці, повчальну літературу, моральні трактати і виявила, що вони ділили дитинство на три етапи з достатньо однорідними ві- 
ковими групами: infantia, pueritia u adolescentia. Infantia (лат. - німота, дітвора, наївність) - період від народження й приблизно до семи років. Тут виокремлюється підперіод десь до двох років, коли в малюка виростають зуби та він може ходити. Окремі автори також акцентували увагу на п'ятирічному віці, коли дитина вже оволодіває мовою. Pueritia (лат. - дитинство, юність) - з семи років до чотирнадцяти в хлопчиків та дванадцяти у дівчаток (настання статевої зрілості). На цьому етапі з'являються здібності вирізняти правильне і неправильне. Разом з тим, як вважалося, в дитини розвивається нахил до гріховності, котрий починався із семи років. Оскільки середньовічні моралісти вважали, що розум дітей таки ще не вповні може осягнути праведне і хибне, тому вони не каралися за злочини, відбували легшу єпитимію, не свідчили в суді, потребували настанов дорослих. Наступний етап - adolescentia (лат. - дозрівання) - від 12 чи 14 років до повноліття. Він вже більше визначався юридичними чинниками: набуттям повного комплексу майнових прав, можливістю свідчити в суді чи нести повну кримінальну відповідальність. Його верхня межа вже $є$ доволі розмитою, дехто встановлював її в двадцять один рік, інші - в двадцять вісім, тридцять, тридцять п’ять років ${ }^{4}$.

Праця Суламіф Шахар дуже важлива, бо показує те, як у сприйманні окремих етапів дитячого розвитку були важливими різні критерії: будова тіла, розвиток мовлення, психіки, здатність розпоряджатися майном тощо. 3 іншого боку, вона грунтується на писемних джерелах, витворених елітарною культурою. Шлях перетікання понять та ідей з таких витворів у свідомість неписьменного суспільства на українському матеріалі малодосліджений. Ми взагалі дуже мало знаємо про вплив текстів на реципієнтів та їхню поведінку, а також те, чи був такий вплив взагалі. Тож наявність якогось припису чи моралізаторства геть не означає, що так було «насправді». Менше 3 тим, видається, що писані релігійні норми в сенсі такого впливу потенційно були успішнішими за світські. Церква більше комунікувала з населенням. Останнє, як носій «народної побожності», мало б бути більш схильним до виконання релігійних приписів ніж світських, оскільки держава була чимось далеким і ефемерним, а «Око Бога» ніколи не спало і все бачило. Церква також мала більше можливостей для прокладання містків між освіченою і традиційною культурою, адже закон тільки встановлює рамки поведінки «наглядає та карає», а релігія ще й дає тлумачення, пояснює і наводить повчальні приклади. Однак чи стосується це уявлень про вік дитинства, зокрема, таких базових моментів, як, наприклад, вживання термінів, котрими маркують дітей різного віку в церковній документації?

Кого і як в цьому сенсі правильно називати, свого часу пояснив на сторінках свого Требника Петро Могила: «Младєнци нарицаютсл дъти ссүщїи млєко, докєлижє глаголати не

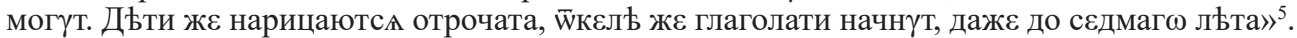
Як бачимо, тут у розвитку дитини виділено дві стадії, котрі не так чітко прив'язуються до віку, як у «правових» періодизаціях. 3 точки зору Требника «младенцем», або ж немовлям дитина вважається доки живиться материнським молоком і не може говорити. Ця межа була і $є$ доволі індивідуальною, і в наш час дитина може почати говорити десь після року життя, але інколи це відбувається й на третьому році (чи ще пізніше), активний запас слів теж формується по-різному. Також автор Требника оперує словом «отрок», ними названі діти, які вміли говорити. Певний логічний наголос фрази дозволяє припустити існуючу за часів Могили традицію називати дітей до семи років «младенцами», а починаючи 3 цього віку - «отроками», котру ієрарх, можливо, хотів підкоригувати й закликав вважати отроками усіх дітей, хто розмовляє, й навіть тих, кому ще немає семи років ${ }^{6}$.

Петро Могила вказав на важливі для Церкви зовнішні ознаки дитячого віку, що були пов'язані і з психологічними. Немовля, котре не мало мови, ще однозначно не належало до дорослого світу, воно було незрозумілим, зрештою, воно не могло сповідатися. Разом 3 тим і отроки, які вже розмовляли, однак не досягли семирічного віку теж вважалися безгрішними, бо ще не могли усвідомлювати свої вчинки «нєразсүднагш ради ихъ оума», а тому не повинні були сповідатися і мали окремий поховальний церемоніал: «по крещенїи оумєршихъ, тьла единъм младєнчєскимъ проводомъ погрђбаємъ» .

Отож вважалося, що ясність розуму, достатня для усвідомлення своїх гріхів, розкаяння чи відповідальність за них (навіть перед Всевишнім) роблять семирічний вік дуже важливим рубежем на шляху дорослішання. Подібний поділ у джерелах XVIII ст. добре простежується, в сповідних відомостях, де у віковому сенсі прихожани були поділені на 
дві групи: ті, хто вже повинен сповідатися і молодші за сім років, які не ходили на сповідь за малолітством ${ }^{8}$.

Про певну значимість цієї межі в церковному дискурсі свідчать і справи іншого характеру. Так, у квітні 1764 р. дячка села Княжичі звинувачували у похованнях дітей без священика. Він зізнався, що інколи самостійно відбував поховальну церемонію за вказівкою ієрея, котрий потім приходив і «запечатував» померлих. Для свого виправдання дячок Назар наголошував на тому, що усі таким чином поховані дітки були не старшими за 7 років9.

Як вже говорилося вище, церковна традиція розглядати семирічний вік як певний «вододіл» має середньовічні коріння. Тодішні моралізатори наголошували на розумінні дитиною (не)правильності своїх вчинків. Разом з тим в цей час дитина вже ставала вразливою для спокус, у неї з'являється нахил до гріховності ${ }^{10}$. А тому, можливо, зовсім не випадково (на противагу цій тезі), біограф Григорія Сковороди Михайло Ковалинський говорить про прояву багатьох чеснот свого вчителя саме у семирічному віці: «...Григорій по седьмому году от рожденїя примътен был склонностью к Богочтенїю, дарованїем к музыкъ, охотою к наукам и твердостїю духа» ${ }^{11}$.

Таким чином, тогочасні релігійні уявлення про дитину пропонували два етапи ії розвитку: вік немовляти та юність. Як показує знайомство з матеріалами церковного обліку населення, наступними (в сенсі зростання) маркерами соціалізації були вже «дівка» та «молодик». Останні радше позначали вже дорослих, але ще не одружених, а тому - ще не до кінця «повноцінних» членів соціуму. Ілюстрацією послідовного і комплексного вживання вікових категорій на позначення різних етапів дорослішання людини в Гетьманщині можуть слугувати записи, зроблені підряд, на відповідній сторінці метричної книги однієї 3 церков Бориспільської протопопії за 1781 р. Так, 5 квітня в удови Зіновії Борисенчихи помер 19-річний син молодик Максим, 6 квітня у Андрія Майстренка - 13-річний син отрок Степан, 7 квітня у Григорія Черпака - 4-річна дочка «младеница» Ксенія (підкреслення моє - I.C. $)^{12}$.

Зрозуміло, що у величезному масиві подібних «недисциплінованих» джерел, можна знайти приклади як дотримання, так і порушення схеми «младенец» - «отрок»«молодык» ${ }^{13}$. Для прикладу відкриємо розділ про померлих метричної книги Христорождественської церкви містечка Яреськи Миргородського полку за 1757-1775 pp. Там за всі 19 років записів зовсім не вживається термін «отрок» ${ }^{14}$, а ті, хто потенційно так міг бути маркований, позначений «младенцем». Що до хлопчиків, то дещо непевна межа між цією когортою та «молодиками» доводилася на 17 років. Я говорю про розмитість межі, бо серед померлих цього віку ми зустрічаємо як «младенців» Якова чи Матвія, так і «молодика» Максима ${ }^{15}$. Починаючи 318 років всі вже записані «молодиками», окрім одного винятку померлого 15 січня 1775 року 19-річного Григорія. 3 поміж усіх інших усопших цього віку, його вирізняє не тільки маркер «младенец», а й те, що він був сином яреськівського священика Олексія Іванова ${ }^{16}$. Що до дівчат, то у їхньому випадку умовна межа доводилася на 13-14 років, оскільки у книзі зустрічаються 13-річні «девицы» та 14-річні «младеницы» ${ }^{17}$. Такі межі для обох статей асоціюються передусім із шлюбним віком ${ }^{18}$, й про це йтиметься дещо нижче, але треба ще трохи розібратися з отроками.

Якщо вказана книга про них зовсім не згадує, то перший же померлий у її продовженні за 1776-1780 pp. (записи зроблені іншим почерком) позначений як отрок. І це був хлопець Григорій віком 1 рік (підкреслення моє - I.C.) $)^{19}$. Важливо, що більше отроків тут немає, всі інші записані так само, як і в книзі за попередні роки, тільки з меншою ретельністю у підборі маркерів, тут ми зустрічаємо 8-річну дівку, або ж навпаки - 15-річну «младеницу» ${ }^{20}$. Подібні приклади свідчать, що схема «младенец» - «отрок» - «молодык», якщо і була, то ідеальною, й давала збій вже в церковних практиках, і тому маловірогідно, щоб вона у XVIII ст. широко «діяла» поза ними та була притаманна уявленням традиційного суспільства.

Цю думку підтверджує той факт, що в джерелах нецерковного походження замість «младенцев», а особливо - замість «отроков», повсюдно вживалася інша лексика. Так, у цивільному діловодстві (найперше в кримінальних справах) найменших діток найчастіше називали «дитя», «ребенок», трішки старших - «мальчик», «девочка», «малолетний» тощо. Маркери 3 цього набору застосовувалися і в Генеральному описі Лівобережної України (коли йшлося не про дітей власників дворів ${ }^{21}$ ), наприклад, служницями в одному 
зі стародубських дворів фігурують 14-річна Агафія та 8-річна Параска. Вони записані підряд, але Агафія позначена як «девка», а Параска - «девочка» ${ }^{22}$. Що до хлопців, то найпоширенішим є маркер «мальчик», зокрема в одному з випадків його застосували до 10-річного Левка ${ }^{23}$. Старші хлопці маркувалися переважно з огляду на їх не вікову, а соціальну приналежність (учень, наймит тощо).

Звісно, що у таких недисциплінованих джерелах, як документація Гетьманщини, можна знайти купу винятків, котрі все ж таки підтвердять правило. Йдеться радше про різні дискурси, які мали власні лексичні набори для маркування дитячого віку ${ }^{24}$. Наприклад, у текстах поета і священика початку XVIII ст. Климентія Зіновіїва представлено мінімум два пласти - «релігійно-освічений» та «народно-популярний». Перший - це повчальні вірші, що акумулюють лексику вченої культури, щодо дитинства там фігурують «младенцы», «отроки», «матки» і т.д. Другий - записані Климентієм народні приказки (приповісті посполиті), витворені традиційною культурою, там немає немовлят та отроків, а $є$ «дитя», «синок» тощо.

Ці дискурси можна розрізняти не тільки у площинах «освіченої» і традиційної культур. Освічена культура, в свою чергу, могла бачити дитинство з релігійної чи більш секулярної точок зору. Так, священик Кирнецький у своєму щоденнику писав, що їде ховати дворічного «младенца», а щоденник Петра Апостола починався із запису про смерть дворічного «мальчика» ${ }^{25}$. У даному випадку два однотипні джерела говорять про речі одного порядку різними мовами.

Вживання різних мов i, відповідно, різних маркерів створює таке собі багатоголосся, у котрому губиться голос неписьменних представників традиційної культури. В судових справах, церковній документації, інших джерелах канцеляристи, священики, чиновники говорили замість простолюду, причому промовляли власною канцелярською мовою. Відтак, якщо вони і вживали термін «отрок», то це ще зовсім не означає, що традиційне суспільство Гетьманщини у зростанні дитини дійсно виділяло юнацький вік (в сучасному розумінні) і тим самим не вписувалося у висновки Філіпа Ар'єса про відсутність в Європі поняття цієї вікової категорії до XIX ст ${ }^{26}$. Можливо, ми якраз спостерігаємо поступове поширення такого розуміння дитинства у релігійному дискурсі «вченої» культури, звідки воно «на практиці» почне поширюватися навсібіч вже у XIX столітті.

Оскільки мова зайшла про «практики», то ще раз наголошу, що дуже важко судити про вплив текстів на їхніх реципієнтів. Хоч щось певне про практичне застосування уявлень «вченої» культури про дитячий вік, можуть сказати історики освіти ${ }^{27}$. Про цей аспект, зокрема, йдеться у спеціальному підрозділі книги Максима Яременка про студентів КиєвоМогилянської академії XVIII ст. 3 точки зору вікових характеристик їхнє середовище загалом було дуже гетерогенним, на думку автора, його можна було б алегорично зобразити «листовим лісом, де одне дерево нижче, інше вище, і висота якого не систематизована по ділянках ${ }^{28}$. Разом 3 тим Максим Яременко поставив питання про літа, які вважалися найкращими для старту освіти в Україні. 3-поміж наймолодших спудеїв Могилянки у 1736-37 pр. він знайшов хлопців віком 8-9 років. Проаналізувавши вік учнів інших тогочасних освітніх закладів, згадки про початок домашньої освіти, спроби державного регулювання (передусім вимоги Синоду до навчання дітей духівництва) Максим Яременко робить генеральний висновок: «досить часто саме семилітній вік фігурує як рубіж, з якого слід було починати перші кроки на шляху здобуття знань». Важливо, що обрання саме семиліття, як рубежу, дослідник пояснює набуттям людиною «церковної дієздатності», тобто усвідомлення (не)правильності своїх дій і відповідальності за них ${ }^{29}$. Таким чином, імовірно, освіта поряд із релігійними требами (напр. залучення дитини до сповіді) були першими сферами, в яких ідеальні уявлення «вченої» культури про дитячий вік знаходили практичне застосування.

Роздумуючи про зміни у ставленні до дитинства в історичній ретроспективі, Х'ю Каннігем (Hugo Cunningham) вживає поняття «розтягування». Йдеться про тенденцію розтягувати дитинство «на Заході» в кінці XIX - на початку XX ст., ключову роль в якій відігравала школа, де поступово збільшували випускний вік, таким чином подовжуючи дитинство ${ }^{30}$. Власне про такі зміни говорив і Ар'є відносно до ранньомодерної Франції, вважаючи головним їх «винуватцем» вузький прошарок еліти (священнослужителі, адвокати, вчені), який першим виявив інтерес до освіти свої чад. Ці ж роздуми схоже, що 
певною мірою накладаються на суспільство Гетьманщини. Воно, без сумніву, відрізняло дитину від дорослого та мало свій власний концепт дитинства, котре було набагато «стиснутішим», або ж коротшим ніж сучасне, і в цьому плані дуже важливим рубежем був, наприклад, семирічний вік.

3 іншого боку, сім років як вік усвідомлення своїх вчинків (долучення до сповіді і т.д.), потім чотирнадцятирічний шлюбний рубіж (двічі по сім), чи «остаточне» повноліття в 21 рік за Саксонським зерцалом (тричі по сім) надто вже очевидно вказують на нумерологічні принципи, запозичені із Середньовіччя. Це частково може пояснити, чому періодизація дитинства виглядає так схематично. Річ не лише у штучному характері сучасної іï (ре)конструкції, а й у тому, що вони не були достатньо природними і для свого часу. Так, відверта нумерологія періодизацій, притаманних середньовічній Свропі, змусила історика Ентоні Барроy (Anthony Burrow) до висновку, що вони не мають ніякого відношення до біологічних та соціальних реалій того часу ${ }^{31}$.

Видається, що будь-яка періодизація буде дуже умовною, адже в той час ставлення до віку, як і до проведення вікових меж, було зовсім іншим ніж зараз. Тодішні люди надавали йому меншого значення ніж тепер, вони не трактували його проміжки як переломні моменти і швидко забували. Це стосується передусім популярної культури. Разом з тим, на матеріалах XVII-XVIII ст. ми можемо побачити як освічена культура (представлена дещо іншими соціальними групами, ніж у Франції) вже стояла біля витоків розтягування. Представники цієї культури вже були носіями специфічних точних слів для опису різних стадій дитинства $^{32}$ і потроху поширювали їх вживання на рівень парафіяльної цивілізації або ж традиційної культури.

1 Див., наприклад, потужний історіографічний есей: Cunningham H. Histories of Childhood // The American Historical Review. 1998. Vol. 103. Issue 4. P. 1195-1208.

${ }^{2}$ Маслійчук В. Дитина та голодні роки (стратегії дорослої та дитячої поведінки на Північному Лівобережжі у 80-х рр. XVIII ст.) // Сіверянський літопис. 2008. № 5. С. 94-99; Сердюк I. Демографічні характеристики дитячого населення Стародуба за даними Генерального опису Лівобережної України 1765-1769 рр. // Наукові записки: збірник праць молодих вчених та аспірантів. Вип. 17. Київ-Хмельницький, 2008. С. 79-100; Сердюк I. Дитина й дитинство в Гетьманщині XVIII ст. // Повсякдення ранньомодерної України. Історичні студії в 2-х томах. Т. 1: Практики, казуси та девіації повсякдення / Відповідальний редактор Віктор Горобець. Київ: Інститут історії України НАН України. 2012. С. 57-86.

3 Чи не єдиною спробою дослідити верхню межу дитинства на основі матеріалів права та судочинства є: Маслійчук В. Вік дорослішання: початок повної кримінальної відповідальності в Лівобережній та Слобідській Україні у другій половині XVIII ст. // Український історичний журнал. 2010. № 2. C. 38-42.

${ }^{4}$ Shahar S. Childhood in the Middle Ages. New York: Routledge, 1990. P. 30-31.

${ }^{5}$ Требник митрополита Петра Могили: У 2 т. [репр. вид. 1646 р.]. К., 1996. Т. 1. С. 727.

6 Зауважу, що в розділі про шлюби у Требнику вживається ще й поняття «юноша», котрим маркуються неодружені хлопці, мовляв одружуватися можуть «юноши» 315 років. Більше цей термін не прив'язується до якогось точного віку, однак бачимо, що йдеться частково і про підлітковий. Див.: Там само. С. 359.

7 Там само. С. 727. Уявлення про дитячу безгрішність потребують окремого фахового дослідження, мова може йти про багато аспектів, зокрема й про семантичне поле «описування» безгрішності на різних рівнях. Так, той же Климентій Зіновіїв уживає поняття «непямятозлобие» у спеціальномі вірші « $\Omega$ нєпамятозло́бія(х) диты́нныхъ». Див.: Зіновїв К. Вірші. Приповісті посполиті / упоряд; І. Чепіга, В. Колосова. К., 1971. С. 129.

8 Див., напр.: Центральний державний історичний архів України, м. Київ (далі - ЦДІАК України). Ф. 990. Оп. 1. Спр. 284.

${ }^{9}$ ЦДІАК України. Ф. 127. Оп. 1020. Спр. 3568. Арк. 2зв.

${ }^{10}$ Shahar S. Childhood in the Middle Ages. New York: Routledge, 1990. P. 30-31.

${ }^{11}$ Ковалинський M. Жизнь Григорїя Сковороды. Писана 1794 года в древнем вкусе // Сковорода Григорій. Повна академічна збірка творів / За редакцією проф. Леоніда Ушкалова. Х.: Майдан, 2010. С. 1344 .

${ }^{12}$ ЦДІАК України. Ф. 990. Оп. 1. Спр. 764. Арк. 107.

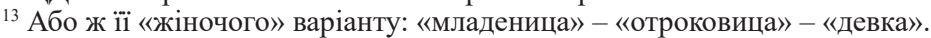

${ }^{14}$ Державний архів Полтавської області (далі - ДАПО). Ф. 1011. Оп. 1. Спр. 157. Арк. 42-63. 
15 Див. напр.: Там само. Арк. 473в., 61-61зв.

${ }^{16}$ Там само. Арк. 42. Виходить, що священик (якщо він вів записи власноруч) чомусь записав свого померлого сина «младенцем», тоді, коли інших писав молодиками. 3 іншого боку, це могло бути співпадінням, або якось пов'язано з тим, що це взагалі перший запис у книзі «о усопших».

${ }^{17}$ Див. напр.: Там само. Арк. 45-45зв., 49зв.

${ }^{18}$ Це логічно, адже для Церкви шлюб, поряд із хрещенням та смертю, був найважливішою подією в житті людини, тож вступ у шлюбний вік однозначно знаменував собою наступний етап життя.

${ }^{19}$ Там само. Ф. 1011. Оп. 1. Спр. 158. Арк. 20.

${ }^{20}$ Там само. Арк. 20, 27зв.

${ }^{21}$ Означені маркери застосовувалися до дітей без батьків. Якщо ж родина мешкала у «повному» складі, то нащадки прив’язувалися до батьків маркером «дети его».

${ }^{22}$ ЦДІАК України. Ф. 57. Оп. 1. Спр. 148а. Арк. 17зв.

${ }^{23}$ Там само. Арк. 86зв.

${ }^{24}$ Я свідомий, що це дуже схематичні та умовні поділи, а межа між такими дискурсами може бути невловимою. Про це, нехай і безвідносно до дитинства, говорив Климентій Зіновіїв - мандрівний священик і поет (кінця XVII - початку XVIII ст.): «Бо в просто(г)[о] мужыка̀ просты(и) е́стъ шбыча(и), а в писмє(н)ныхъособны(и) польты(ч)ны(и) звы́ча(и)». Див.: Зіновї̈в К. Вірші. Приповісті посполиті / Упоряд.: І. Чепіга, В. Колосова. К., 1971. С. 90.

${ }^{25}$ На жаль, я не можу перевірити як «мальчик» фігурував у щоденнику Данила Апостола в оригіналі, тож мушу довіритися перекладу. Див.: Щоденник Андрія та Федора Кирнецьких, священиків Свято-Миколаївської церкви с. Ховзовки Глухівського повіту Новгород-Сіверського намісництва (грудень 1787 - жовтень 1788 рр.) / Упор. та вступна стаття І. Ситого. Чернігів, 2006.

${ }^{26}$ Ця ідея є одним із основних лейтмотивів відомої книги Філіпа Ар’єса: Арьес Ф. Ребенок и семейная жизнь при старом порядке. Екатеринбург: Издательство Уральского университета, 1999.

27 Йдеться про невелике коло фахових дослідників освіти в Гетьманщині, але жодною мірою не про так званих «істориків» педагогіки.

${ }_{28}$ Яременко М. «Академіки» та Академія. Соціальна історія освіти й освіченості в Україні XVIII ст. Харків: Акта, 2014. С. 60.

${ }^{29}$ Там само. С. 64.

${ }^{30}$ Cunningham H. Histories of Childhood // The American Historical Review. 1998. Vol. 103. Issue 4. P. 1195-1208.

${ }^{31}$ Burrow J. A. The Ages of Man: A Study in Medieval Writing and Thought. NewYork: Oxford University Press, 1986. P. 34. Взагалі вся ця книга присвячена дослідженню концептів віку та його періодизацій. Ентоні Барроу проаналізував великий масив середньовічних текстів (літературного, релігійного, медичного, політичного характеру), зображень тощо і дійшов до висновку, що - різні періодизації, котрі пропонували три, чотири ... сім стадій, все рівно грунтуються на нумерологігії, прив'язуючись чи то до семи планет, чи то канонічного циклу, чи до чотирьох рідин організму. Більш концентровано див. напр. рецензію на книгу: Penny S. Gold. Review of "The Ages of Man: A Study in Medieval Writing and Thought" // The American Historical Review. 1988. № 93 (3). P. 677-687.

${ }^{32}$ Використання таких понять в різних сферах культури та діловодства в Європі епохи Відродження було важливим аргументом в критиці теорії Ар'є дослідницею Барбарою Ханавалт. Див.: Hanawalt B. The Child in the Middle Ages and the Renaissance // Koops W., Zuckerman M., eds. Beyong the Century of the Child: Cultural History and Developmental Psycholodgy. Philadelphia: University of Pennsylvania Press, 2003. P. 33. 